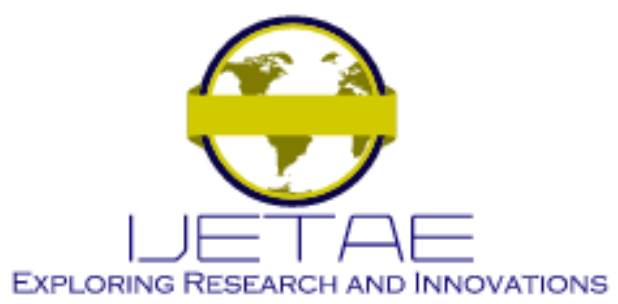

International Journal of Emerging Technology and Advanced Engineering

Website: www.ijetae.com (E-ISSN 2250-2459, Scopus Indexed, ISO 9001:2008 Certified Journal, Volume 11, Issue 11, November 2021)

Manuscript Received: 04 October 2021, Received in Revised form: 07 November 2021, Accepted: 11 November 2021

DOI: $10.46338 /$ ijetae1121_25

\title{
A Novel Approach of Analysis of the Banking Market, Case Study Bank Financial Institution
}

\author{
Dr. Samuel Lara Escamilla ${ }^{1}$, M.E. Ivett Vásquez Lagunas ${ }^{2}$, Dr. Pedro Arturo Chávez Reyes ${ }^{3}$, \\ Ing. Felix Vázquez Martínez ${ }^{4}$ \\ ${ }^{I}$ Professor in the Division of Postgraduate Studies and Research at National Technology of Mexico, Technological Institute of \\ Tlalnepantla. \\ ${ }^{2}$ Professor in the Administrative Economics Department at National Technology of Mexico, Technological Institute of \\ Tlalnepantla. \\ ${ }^{3}$ Professor in the Division of Postgraduate Studies and Research at National Technology of Mexico, Technological Institute of \\ Tlalnepantla. \\ ${ }^{4}$ Master of Administration student in the National Technology of Mexico, Technological Institute of Tlalnepantla.
}

\begin{abstract}
This research explores the ideas raised through the authors Gaither and Frazier (2000). Reengineering arises when capacity needs change or market conditions change. These elements propitiate a transformation to a digital age. The digital age or digital revolution is based on new technologies and has as key factors: the Internet. Information technology. Big data. Artificial intelligence These changes and transformations force organizations to apply various reengineering plans to be able to cope with these changes and stay in the market and with their consumers. Reengineering is the fundamental change to get to the base of the organization's problems (Hammer and Champy, 1994), so it is very common for organizations to find themselves in constant changes in order to meet the demands of their markets, consumers. and competitors. The object of study of this research is to propose an autonomous system for the analysis of the banking market.
\end{abstract}

Keywords - autonomous model, artificial intelligence, implementation, industrial revolution, e-commerce

\section{INTRODUCTION}

Gaither and Frazier (2000) mention: planning of processes for new products and services is intense. The environment, conditions and needs of the market are constantly changing, along with the services and the way in which they are provided; therefore, organizations invest resources, human capital and infrastructure to face these adversities. In figures from the United Nations (UN), approximately 20 years ago, digital technologies reached our societies and markets.
Currently technology has reached about $50 \%$ of the world's population and transformed nations; technological advances have changed the ways and means in which things are done. The uses and technological applications are multiple and diverse, through electronic means it is possible to communicate, enter an extensive portfolio of products and services; in addition, the entry to multiple electronic commerce channels, as well as the consultation of different sources of information to mention the multiple uses that it can be given.

\section{METHOD DESCRIPTION}

The implementation of an autonomous artificial intelligence model will be analyzed; by studying the operating data of the model, in order to identify patterns and deviations during the execution of its tasks in order to maximize the operation of the tool and develop automatic learning with the operational information it processes in one day. Of the multiple benefits that are expected, the following are listed: reduction of attention times. Minimizing operating losses caused by human error. Realtime operational reports; This will allow the timely detection of possible incidents that could originate in any of the phases of the electronic commerce cycle and make forecasts of future demand; in addition, the development of fraud prevention models that allow us to identify fraudulent operations in a timely manner and develop statistical models for decision-making. 


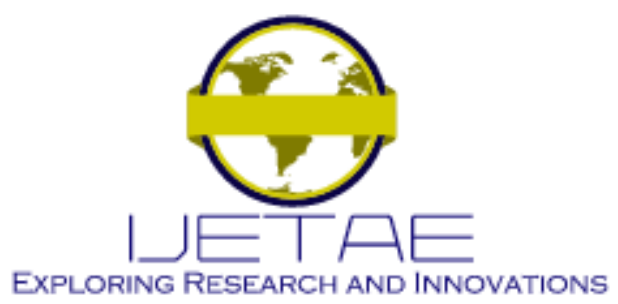

International Journal of Emerging Technology and Advanced Engineering

Website: www.ijetae.com (E-ISSN 2250-2459, Scopus Indexed, ISO 9001:2008 Certified Journal, Volume 11, Issue 11, November 2021)

Hypothesis The use of the autonomous system will make it possible to satisfy the demand for claims, derived from the after-sales services originating from the monetary operations that are executed on the various platforms and applications that operate in the channels intended for electronic commerce. This will bring us as a benefit: The reduction of operating losses and financial penalties for the mishandling of information. Greater efficiency in the processes generating the reduction of times of attention to the claims Free to the human fronts to carry out more specialized tasks. Obtain real-time reports regarding the operation, which will help us to forecast future demand, timely detection of incidents and support decision-making With its implementation, gradual reductions of $3 \%$ are expected on the operating volume generated by the increase in services post-sale.

\section{PROBlEM STATEMENT}

Stage 1: it is the reception of the claim in the various service channels. The data of the operation to be claimed is entered and it is sent through the institutional systems of the institution.

Stage 2: It is divided into five steps, which are described below:

- Step 1: claims are received and the information is initially processed, if it does not correspond, the claim is closed, if it continues, proceed to the next step

- Step 2: the transaction values and encryption are analyzed

- Step 3: enter the institutional systems and retrieve additional data for the operation; as well as evidence of it.

- Step 4: electronic formats are filled out with the previously recovered data, the evidence is attached and the document is converted to the format supported by the clearinghouse platform

- Step 5: enter the clearinghouse system and proceed with it, sending the information and file related to the claim.
Stage 3: Feedback from the merchant is received and the claim is closed. When carrying out the analysis of the process, it was identified that the most complicated stage in the treatment of claims is stage number two, which consists of a series of steps where the bottlenecks originate; Due to the fact that in its various steps it does not have the infrastructure and capacity to process claims in a more agile way.

Preparation of the study of times and movements In order to carry out the reengineering, it is necessary to know the times with which each step is executed. In order to obtain this measurement, a virtual operating assistant (VOA) was designed; that measures the time in which the tasks are executed according to each step, based on the use of the applications and systems, without accounting for the idle time in the system. This made it possible to obtain the measurements of the operation by dividing each one of the movements carried out in order to process the claim and the times needed to attend to each one were standardized. The table represented in table 1 shows the approved operating time obtained with the support of the VOA, during the month of February 2020.

Table 1 Results of the analysis of times for the month of February 2020

Table 1

Time to service and attend request

\begin{tabular}{|l|l|}
\hline STEP & TIME \\
\hline Step 1 & $00: 00: 40$ \\
\hline Step 2 & $00: 00: 24$ \\
\hline Step 3 & $00: 02: 00$ \\
\hline Step 4 & $00: 01: 55$ \\
\hline Step 5 & $00: 00: 25$ \\
\hline Average time to attend request & $00: 05: 24$ \\
\hline
\end{tabular}

Note: According to the data obtained and which are reflected in figure 1, the steps that used the most time are three and four; in turn, the total time required to process the claim is 05 '24" (five minutes, twenty-four seconds).

In order to postulate improvements and apply reengineering, forums were held with the working groups to identify deficiencies and operational needs that cause bottlenecks and that represent an increase in claims processing times. The main ones are mentioned below: 


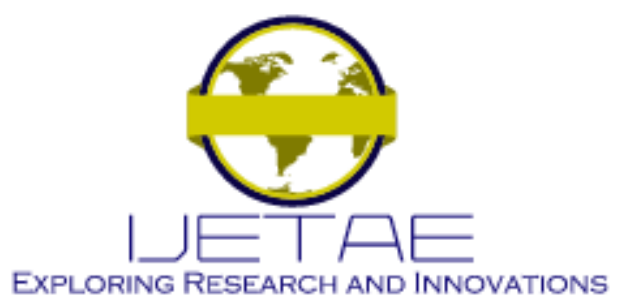

International Journal of Emerging Technology and Advanced Engineering

Website: www.ijetae.com (E-ISSN 2250-2459, Scopus Indexed, ISO 9001:2008 Certified Journal, Volume 11, Issue 11, November 2021)

- The complexity for consulting the information in the institution's systems

- The individual treatment of information (filling in electronic forms, annex of evidence and file conversion)

- Time is spent interacting with menus and interfaces that require repetitive actions

- The handling and processing of data (when handling large amounts of information, the risk of making mistakes increases).

Based on the detected areas of opportunity, brainstorming was carried out in order to find optimal solutions that make the handling of claims more efficient. The ideas that were collected are:

- The creation of simplified tools for consulting information in institutional systems Step Time Step 1 00:00:40 Step 2 00:00:24 Step 3 00:02:00 Step 4 00:01:55 Step 5 00: 00:25 Average service time per request 00:05:24 48

- The elaboration and massive filling of electronic formats

- Greater agility in the interaction with the various graphical interfaces and web platforms that are repetitive

- The automatic transport of information to the various platforms

Updating the flow chart with the implementation of the tools

With the incorporation of macros, the way of performing the tasks of steps two and three of stage number two was modified. Next, figure 1 shows the updated flow from the use of the new tools.

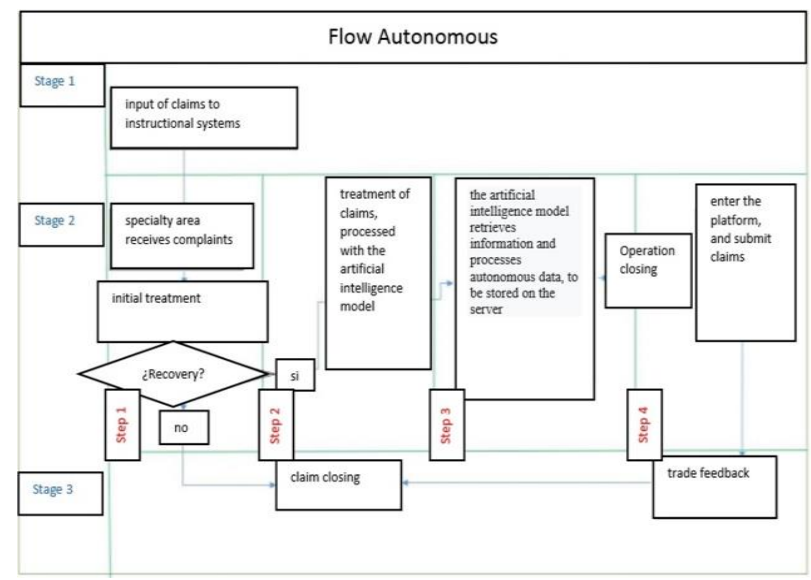

Source: self made
From figure 1, Next, the new way of executing the steps by which claims are handled is described, from the moment the macros were implemented.

\section{Stage 2}

Step 1: claims are received and the information is initially processed.

Step 2: the transaction values and encryption are analyzed

Step 3: The claim information is entered into the macro and it is executed. With this procedure the following are obtained: complementary data of the claim and the evidence thereof

Step 4: the information obtained in step three is copied and the template is entered. The macro associated with the template is executed and the files with which the claims will be managed are obtained.

Step 5: enter the clearinghouse system to make the request and send the documentation

\section{Operational map of the autonomous model.}

In order to develop the software, a map of the movements and decisions made by the artificial intelligence model was developed. Next, in figure 2. a diagram of the operation of the autonomous model is represented. The movement map developed allowed to identify the movements that should be considered for its operation.

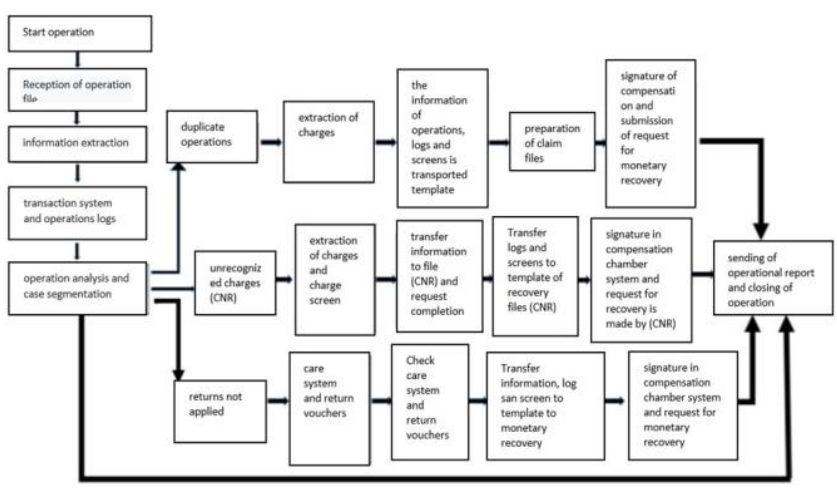

Source: self made

The steps that the model will perform are described below.

- The operating input is deposited in the server destined for the autonomous system. 


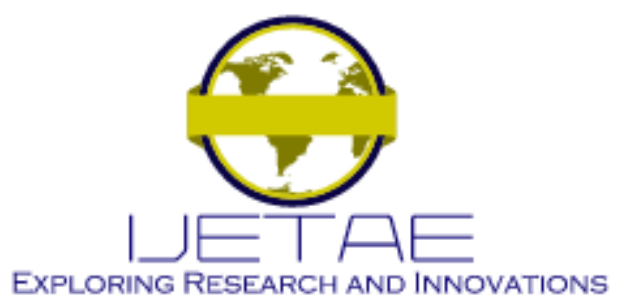

International Journal of Emerging Technology and Advanced Engineering

Website: www.ijetae.com (E-ISSN 2250-2459, Scopus Indexed, ISO 9001:2008 Certified Journal, Volume 11, Issue 11, November 2021)

- The artificial intelligence model enters the server path, extracts the file and opens it; to start extracting information from the operation.

- Open an internet browser, enter the link of the transaction consultation system, enter security credentials (user and ID) to the system, navigate through interactive menus and search for operations. Identify the operations and perform a reading of numeric values and retrieve the log of the operation.

- According to the values read, it will segment the operation according to the treatment that will be given.

\section{Duplicate charges}

- Duplicate operations: open an internet browser session and enter the account statements link; authenticates with security credentials. Interact with menus, enter position information and extract screens from the system.

- With the information of the operation and the system screens, the model transports the information to the template to make the files.

- Create the format and convert the claim files

- Open internet browser, enter the clearinghouse system link, enter username and ID, navigate through interactive menus and make the request for monetary recovery.

- Feedback operation report file

\section{Unrecognized charges}

- Open an internet browser, enter the account statement system link, enter user and ID, navigate interactive menus, extract information and display the charges.

- Transports the information to the recovery letter template for unrecognized purchase and makes the letter.

- Transports the information and screens to the format to prepare the files attached by CNR

- Open an internet browser, enter the clearinghouse system link, enter user and ID, navigate through options menus and fill in fields related to the claim, attach files and send the recovery request for unacknowledged purchases.

- Feedback operation report file

\section{Refund not applied}

- Open an internet browser session, enter the customer care system link, enter username and ID, navigate through option menus and search for the claim. Enter the file and extract the return vouchers.

- Enter the account statement league, enter user and ID, navigate through options menus and search for the movement, extract the charge screen.
- Transports the information and recovered documents (log, charge screen and return receipt) to the template and performs the file to recover the monetary operation.

- Open internet explorer, enter the clearinghouse system link, enter user and ID, navigate in options menus and fill in fields related to the claim, attach files and send the recovery request for unrecognized purchases

- Feedback operation report file

Functionality tests.

Software version 1.1 of the artificial intelligence model was received from the developer.

In order to carry out the operation of the autonomous model, modifications were made to the institutional platforms, systems and applications so that it can carry out the tasks related to the operation. In addition, the virtual environment under which they will be developing their tasks was prepared. The security ciphers of institutional systems have been adjusted so that the model can perform its tasks without restrictions due to its computing nature.

To perform the functionality tests, a batch of 500 claims was assigned to the model through its operating input file. The assignment will serve as a sample to measure the level of effectiveness of the artificial intelligence model.

According to the type of cases, the results that are expected to be obtained from the operation of the autonomous model in the operational report, the results will be identified according to the following claim states:

Accepted - The claim was successfully processed.

Rejected: the claim did not meet the requirements for your operation or it does not apply.

Pending - The claim could not be processed by the model.

Error: the autonomous model did not recognize and / or did not identify a parameter. Or it is different from the programming values.

The operation input file was deposited to the server, a volume of 500 claims was assigned and the following results were obtained, which are represented in the table 2

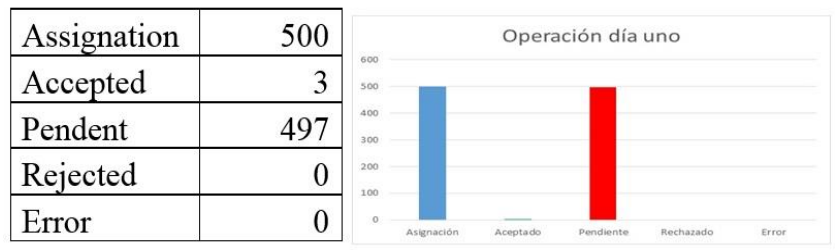

Source: own elaboration (operation report of the autonomous model day one, June 8, 2020) 


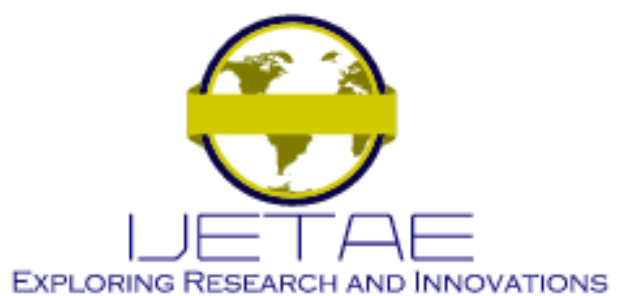

International Journal of Emerging Technology and Advanced Engineering

Website: www.ijetae.com (E-ISSN 2250-2459, Scopus Indexed, ISO 9001:2008 Certified Journal, Volume 11, Issue 11, November 2021)

From the artificial intelligence model; in which, its operation was segmented into two schedules. The start of operation of the model will take place at 06:00 a.m. CDMX time (UTC-6), the cut-off will take place at 05:45 p.m. and at 06:00 p.m. The second phase of operation of the model begins (step four), which consists of submitting claims through the clearinghouse platform.

According to the times obtained on day six of the tests, a batch was prepared with a total input of 800 claims and it was deposited on the server for execution. The results are presented in the table that is represented in table 3

After the implementation of the autonomous system with artificial intelligence, it can be seen that the demand is accepted and there are fewer rejections compared to day 1 , see table 3

\begin{tabular}{|c|c|c|}
\hline Assignation & 800 & Operación día diez \\
\hline Accepted & 579 & $\begin{array}{l}800 \\
700\end{array}$ \\
\hline Pendent & 60 & $\begin{array}{l}500 \\
300 \\
400\end{array}$ \\
\hline Rejected & 27 & $\begin{array}{l}300 \\
200\end{array}$ \\
\hline Error & 134 & 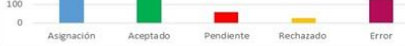 \\
\hline
\end{tabular}

Source: own elaboration (operation report of the autonomous model day one, June 30, 2020)

Findings:

- Online time step three: 11:51:28

- Estimated time of attention to claim step three: 00:00:58

- Volume processed: 740 claims

- Online time step four: 3:41:57

- Estimated time of attention to claim step four: 00:00:23

- Volume processed: 579

\section{CONTRIBUtions OF OUR PROJECT}

\section{Results of claims processing time}

Ten days of autonomous model operation functionality tests were conducted.

Through which the main deviations and errors of the algorithm were identified and corrected; however, new issues may arise due to changes in institutional or vendor programs and applications.

In addition to the fact that some other factor may be present that has not been analyzed during this testing period.
With the manual operating time developed with the AOV for the month of February 2020, the initial operating times are 00:05:24 (five minutes, twenty-four seconds).

This measurement is taken as a basis; the objective of the autonomous model is to reduce claims processing times.

Next, in figure 3 the evolution of the times from days one to ten is graphically presented, taking as a basis and defined as day zero the average time obtained in the period of February 2020.

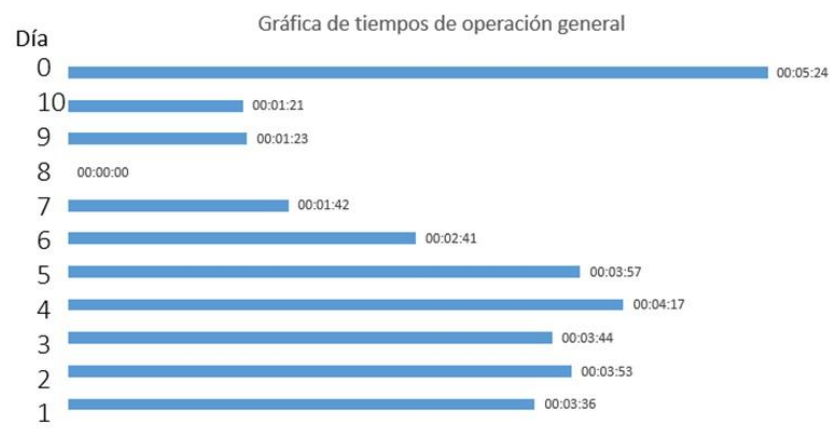

So in an analysis in times, from day zero and day ten, a considerable reduction in the processing times of claims can be seen. The testing stages made it possible to optimize the tool, considerably reducing the execution times of the activities.

\section{General CONCLUSIONS}

With The Results Obtained From The Functionality Tests Of The Artificial Intelligence Model; According To The Rate At Which The Claims Are Born, For The 2020 Figures Which Are 40.5 Seconds. It Has A Capacity To Process Claims Of 01:21 Seconds, As Opposed To 05:24, Which Was Manually Operated.

With The Average Rate Of Attention To Claims Obtained In The Testing Period, It Indicates That For Every Two Claims Made Through The Use Of The Electronic Commerce Channel, The Model Will Be Able To Attend One. This Means That By Replicating The Algorithm, It Will Be Possible To Obtain The Capacity To Attend To The Claims Of The Electronic Commerce Channel.

Based On The Results, It Is Concluded That It Will Be Achieved: 


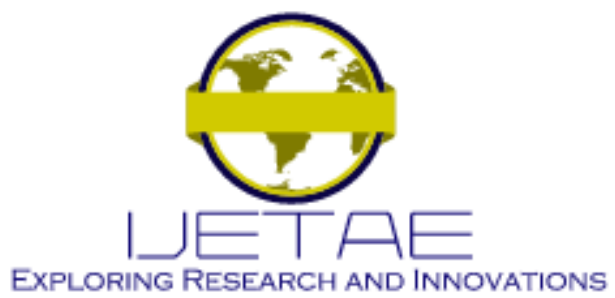

International Journal of Emerging Technology and Advanced Engineering Website: www.ijetae.com (E-ISSN 2250-2459, Scopus Indexed, ISO 9001:2008 Certified Journal, Volume 11, Issue 11, November 2021)

- Free up the human fronts that are in charge of processing e-commerce claims.

- Reduce the processing times for claims by electronic commerce.

- Greater control of the operation through operational reports in real time.

- Reduce errors, the treatment and transport of information is automatic; therefore, the processed information is more reliable

\section{BIBLIOGRAFY}

[1] ADEN Business Magazine (30 de julio de 2020) ¿Cómo las nuevas tecnologías están impactando en el sector financiero?, Recuperado a partir de https://www.aden.org/business-magazine/las-nuevastecnologias-estan-impactando-sector-financiero/

[2] Asociación de Bancos de México (ABM, 2021) Bancos asociados. Recuperado a partir de https://www.abm.org.mx/bancos-integrantes/

[3] Barba Á. (sin año) Frederick Winslow Taylor y la administración científica: contexto, realidad y mitos. Repositorio Institucional Zamoamati UAM. Recuperado a partir de http://zaloamati.azc.uam.mx/bitstream/handle/11191/2955/frederickwinslow-taylor-y-laadministracion-cientifica-contexto-realidad-ymitos.pdf?sequence $=1$
[4] Bonilla-Pastor-de-Céspedes, E., Díaz-Garay, B., Kleeberg-Hidalgo, F., \& Noriega-Araníbar, M. T. (2010). Mejora continua de los procesos: herramientas y técnicas. Universidad de Lima. Fondo Editorial.

[5] Gaither, N., \& Frazier, G. 2000. Administración de producción y operaciones (Vol. 8). International Thomson.

[6] Hammer Michael y Champy James 1994, Reingeniería, Editorial Nava, Colombia.

[7] Hammer, M. Y. 1994. Reingeniería. Santa fe de Bogotá. Norma

[8] Luna González, A. C. 2014. Proceso administrativo. Grupo Editorial Patria.

[9] Münch, L. 2010. Administración. Pearson Educación.

[10] Ponce, A. R. 1992. Administración moderna. Editorial Limusa.

[11] Rankia (25 de marzo de 2021) Mejores bancos de México 2021. Recuperado a partir de https://www.rankia.mx/blog/mejoresopiniones-mexico/3452821-mejores-bancos-mexico-2021

[12] Vázquez Burguillo, R. (31 de octubre, 2015). Cámara de compensación. Economipedia.com, recuperado desde: https://economipedia.com/definiciones/camara-decompensacion.html 